\title{
What a Second Chamber can do for legislative scrutiny
}

\author{
by Lord Hope of Craighead
}

The Third Annual Sir William Dale Memorial Lecture was given at Senate House, University of London, on 27 October 2003 by The Rt Hon The Lord Hope of Craighead, Chairman of the Advisory Council of the Institute of Advanced Legal Studies. The lecture was organised by the Sir William Dale Centre for Legislative Studies, and is reproduced below.

It is a very great honour for me to have been invited to give this, the third, lecture in this annual series in memory of Sir William Dale which is organised by the Centre for Legislative Studies that bears his name. As my predecessor Lord Goldsmith remarked the last time we met, Sir William's career was one of tremendous scope and achievement. His name is celebrated above all in the field of legislative drafting, but the range of his interests was very wide. This was borne in on me earlier this year when we were referred in the course of a hearing of an appeal in the House of Lordsto the first of his many published works, The Law of the Parish Church (see Aston Cantlow and Wilmcote with Billesley Parochial Church Council v Wallbank [2003] UKHL 37, [2003] 3 WLR 283). It first made its appearance in 1932 and ran to no less than seven editions under his own hand during his lifetime: the seventh edition was published in 1998. It has been described as a little gem, and he is recorded as having admitted that the fact that it went through seven editions over 66 years under the same authorship was probably a record. Then there was music - everything except Wagner, as he put in his entry in Who's Who. But by 1977 it was legislative drafting that had captured his attention. He wrote about its practice in the modern Commonwealth and he compared our methods with those in use in France, Germany and Sweden (see Legislative Drafting: A New Approach (1977); The Modern Commonwealth (1983); (ed) Anglo-French Statutory Drafting (1987)).

For much of his life, of course, he was very active in this field. He did so much to set the highest standards for those who would follow in his footsteps.

What Sir William did not have time to do before he died was study how legislative drafting was working out under the devolved system in the Scottish Parliament. I should like to devote the first part of this lecture to that topic. I shall devote the other part to the work of the Select Committee of the House of Lords which is charged with scrutinising legislation emanating from the European
Union. Although the subject matter covered by these two fields of legislation is very different both in scale and content, there is a common theme. It is the contribution which a Second Chamber can make to the work of a modern legislature. We have a Second Chamber at Westminster, but the bicameral model was rejected by those who designed the system which has been adopted for Holyrood. There are some who think that the Scottish Parliament should have a Second Chamber. On the other hand when the various options that had been suggested for reform of the House of Lords reform were voted on in both Houses on 4 February this year, more than a hundred MPs voted in favour of a motion that the Second Chamber at Westminster, the House of Lords, should be abolished altogether. So there is a debate going on both north and south of the border as to whether there is anything at all to be said for having a Second Chamber in our legislatures. If there is a good reason for having one, it must surely lie in what a Second Chamber can do for legislative scrutiny.

\section{THE SCOTTISH PARLIAMENT}

Section 1 of the Scotland Act 1998 established a unicameral Scottish Parliament. As had been proposed in the White Paper Scotland's Parliament (Cm 3658 (1997), the Act was designed to provide a framework for the Parliament, leaving it open to the Parliament itself to develop the procedures that would best meet its purposes. It was, of course, starting with a clean sheet. But a good deal of thought was given to how it might operate before the Act was passed. A consultative steering group was established by the Secretary of State for Scotland on which all four main political parties in Scotland, including the Scottish National Party, were represented. Its purpose was to consider the operational needs, working and procedures of the Parliament with a view to the preparation of draft standing orders for possible adoption when it convened after the elections for its membership had been completed.

It was clear that an essential role in the legislative process would be played by committees. As there was to be 
no Second Chamber, the entire process of scrutinising Bills, revising their content and ensuring that they would work in practice was to be conducted either by the Parliament as whole or by committees. The committees were to have the responsibility of conducting the detailed scrutiny of these measures. They were to have power to take evidence from interested parties as part of this process where this was appropriate. The use of the committee system was seen as a positive and modern development. The expectation was that the Scottish Parliament would, by using this system, be much closer to the people it was designed to serve than the Westminster Parliament, which was widely perceived to be too remote. It was also expected that the usual rule would be that legislation about devolved subjects in Scotland would be enacted by the Scottish Parliament. Legislation at Westminster with regard to devolved matters was expected be infrequent (see HC Deb, Vol 305, cols 402-403, 28 January 1998, Donald Dewar, Secretary of State for Scotland; SP OR, 9 June 1999, col 358, Donald Dewar, First Minister), and then only with the agreement of the Parliament at Holyrood. During the debate on section 28(7) of the Scotland Act, which states that the power of the Scottish Parliament to make laws does not affect the power of the Parliament of the United Kingdom to make laws for Scotland, the Minister of State, Lord Sewell, announced that the Government expected a convention to be established that Westminster would not normally legislate with regard to devolved matters in Scotland without the consent of the Scottish Parliament ( HL Deb, 21 Jul 1998, col 791.) The convention which has resulted is known colloquially as the Sewell Convention after the Minister of State, Lord Sewell, who was responsible for it: for a detailed analysis of the procedures and the justifications which have been given for using it, see Noreen Burrows, This is Scotland's Parliament; Let Scotland's Parliament Legislate [2002] JR 213.

The basic structure that was worked out for the passage of a Bill through the Parliament was this. Following its introduction a Bill was to be referred to an appropriate committee for consideration in principle. This was to be known as Stage 1. It was to be completed by the submission of a report, the Stage 1 Report, for debate in principle by the whole Parliament, equivalent to a Second Reading debate at Westminster. The Bill was then to be returned to the committee for further debate and detailed scrutiny, equivalent to what is known at Westminster as the Committee Stage. This was to be known as Stage 2. When this stage was completed the Bill was to be presented for debate and final approval by the whole Parliament. This was to be known as Stage 3, combining the Report and Third Reading debates at Westminster. It was to be the only stage when the whole Parliament was to have an opportunity of considering the Bill in detail. But the opportunity for making amendments to it was to be limited by a rule that the only amendments that could be taken were those selected by the Presiding Officer. The whole
Parliament was, of course, to have ultimate control over the entire process, with power to remit a Bill for further consideration at Stage 2 if necessary.

Standing Orders were then prepared in draft and approved by the Parliament. They provide that there are to be eight mandatory committees: those dealing with the basic functions of procedures, standards, finance and audit and those dealing with equal opportunities within the Parliament, petitions to the Parliament from members of the public, proposals for legislation by the European Union and subordinate legislation. But the Parliament also has power to establish committees dealing with specific subject areas. In the performance of its legislative function this is where the real action lies. The specific subject areas which were chosen for this purpose by the first Parliament following the 1999 election were nine in number, as follows: (1) education, culture and sport, (2) enterprise and lifelong learning, (3) health and community care, (4) justice and home affairs (known as justice 1 and justice 2), (5) local government, (6) rural development, (7) social inclusion, housing and the voluntary sector and (8) transport and the environment. There was some restructuring of these arrangements following the 2003 election. Health and education now have committees of their own. Culture has been put with enterprise, the environment has been put with rural development and transport has been added to local government. Social inclusion, housing and the voluntary sector has been renamed communities. The net effect is a reduction in the number of these committees from nine to eight.

All these committees are required by rule 6.2 of the Standing Orders to examine such matters within their remit as they may determine appropriate or as may be referred to them by the Parliament. But that is not all. They are also required by the rule to conduct inquiries into matters falling within their remit, consider the policy of the Scottish Executive and proposals for legislation whether before the Scottish Parliament or the United Kingdom Parliament, consider any European Union legislation or any international covenants or agreements, consider the need for the reform of the law and initiate Bills on any competent matter.

This is a formidable list of responsibilities. Bear in mind that the Parliament has only 129 members. The committees have between 5 and 15 members, so every member can expect to be heavily engaged in committee work. The Office of the Scottish Parliamentary Council is responsible for drafting Bills to be put before Parliament by the Executive and the handling of all associated work on Bills as they are working their way through the system such as the preparation of amendments to deal with points suggested by members or by the Executive. It is staffed by only four Scottish Parliamentary Counsel and their seven assistants.

As for the legislative output of the Parliament, it produced during its first term of four years 54 Executive 
Bills, 6 Members Bills and 2 Committee Bills - a total of 62 Bills, all of which have received the Royal Assent. This represents on average 13 Bills each year, compared to about four each year before devolution. Then there is delegated legislation. In 200217 Bills were passed by the Parliament, but so were about 550 Scottish Statutory Instruments. And many of the more than 4,000 Statutory Instruments made in London that year had to be looked at by the Subordinate Legislation Committee as they were to apply throughout the United Kingdom including Scotland. Then there is the huge volume of proposed legislation by the European Union, about which I shall be saying something in the second part of this lecture. This too had to be scrutinised by the Parliament's European Committee in so far as it affected devolved matters. From time to time legislation by the United Kingdom Parliament by agreement with the Scottish Parliament contains provisions relating to Scotland in devolved matters under the Sewell Convention that Westminster would not normally legislate with regard to devolved matters in Scotland without the consent of the Scottish Parliament. (It has been restated in a Memorandum of Understanding to that effect, Cm 4806 (2000), para 13, and see also the earlier reference to HL Deb, 21 Jul 1998, col 791) . So this has to be taken into account as well. How is all this working out in practice? Is it too much for a single chamber to handle on its own?

\section{HOW IS THE SCOTTISH PARLIAMENT WORKING IN PRACTICE?}

To begin with there were some impressive achievements. The very first enactment passed by the Parliament was the Mental Health (Public Safety and Appeals) (Scotland) Act 1999. It was an emergency measure, as the name suggests. It dealt with a problem that had arisen about the legislation relating to restricted patients, commonly known as psychopaths, detained under the Mental Health (Scotland) Act 1984 on grounds of public safety. Following a recent decision in the House of Lords they could no longer be detained under that Act, as there was no form of treatment that was capable of alleviating or preventing any further decline in the medical condition from which they were suffering $R_{v}$ Secretary of State for Scotland [1999] 1 All ER 481, 1999 SC (HL) 17.

Stage 1 of this Bill took place on 2 September 1999, the day after the Parliament commenced business for the first time, and its passage was completed on 8 September 1999 when, after Stage 3 was completed, the Bill was passed by the Parliament. It survived scrutiny by the Judicial Committee of the Privy Council when it was challenged as being outside the competence of the Parliament on Human Rights grounds in Av The Scottish Ministers, 2001 SC (PC) 63.

Many of the Bills which were passed by the Parliament in the first two sessions of its first four year term were remarkably short and succinct as compared with much of the legislation that emanates from Westminster. Overall, there is a simplicity of style and tightness of language that would certainly have appealed to Sir William Dale. But there were some very important and quite complex measures too. The Adults with Incapacity (Scotland) Act 2000 (2000, asp 4), which has 89 sections and six Schedules, has rightly been described as a radically reforming Act, creating in Scots law a coherent modern code of provisions as to decisions about the personal welfare of adults with incapacity and the management of their property and financial affairs (see the general note on the Act in Current Law Statutes). And the Abolition of Feudal Tenure etc (Scotland) Act 2000 (2000, asp 5), which has 77 sections and 13 Schedules, took the fundamental and long-awaited step of abolishing the feudal system of land tenure in Scotland and addressed all the various consequences of doing so. These two examples were high points in the early stages of the legislative programme, as were the Standards in Scotland's Schools etc Act 2000, asp 6, and the Bail, Judicial Appointments etc (Scotland) Act 2000, asp 9.

They were promoted, of course, by the Scottish Executive with the benefit of advice in the matter of drafting from the Scottish Law Commission from whom these Bills originated. There was little political controversy. They were measures that would have had to wait for a long time in the queue for enactment at Westminster, where there was room for only a few Scottish Bills in any one session and much pressure to keep those Bills as short as possible. Here we see the system of devolution at its best, and there is nothing here that suggests that the unicameral system was operating in any way to Scotland's disadvantage.

But there are signs elsewhere that the system is coming under increasing pressure and may indeed be suffering as a result. There was, of course, always a risk that politics would take over and demands made for the introduction of unorthodox and populist measures which would test the Parliament's legislative skills to the limit and result in legislative overload. If those who draft the measures which are to be placed before the Parliament are to be enabled to do their job properly decisions are needed in sufficient time for this to be done from Ministers, and there should be as few changes of direction as possible once the Bill has left the draftsman's hands and started to go through the parliamentary process. But we live in an imperfect world, and even the most experienced parliamentary draftsman would admit that detailed scrutiny is essential as a Bill works its way through the legislature. The more the first draft is exposed to amendment the more important that scrutiny becomes.

Experience of the present system in the Scottish Parliament has shown that, while there is plenty of policy, MSPs take little interest in the detail. And there is an increasing demand for quick product from the parliamentary draftsmen and for too much legislation, with perhaps too few people on hand to do the job. The 
committee system, which was designed to provide an opportunity for careful, informed study of all the relevant detail, is not working as it should. Responsibility for both initial scrutiny of a Bill at Stage 1 and detailed scrutiny at Stage 2 rests with the same committee. At both stages this process tends to become the focus for political debate and point-scoring. Elected committee members lack the independence of mind and the opportunity for detachment and genuine self-criticism that is essential to effective scrutiny. Not surprisingly political debate predominates when the Bill comes before the whole Parliament at Stage 3. But the opportunity for detailed scrutiny is all but over by that stage. If there is to be detailed scrutiny under the present system, it has to be by the committees.

The problems which legislative overload can cause is, of course, familiar at Westminster too. Lord Rodger of Earlsferry, who was a government law officer for several years before he became a judge and sat in the House of Lords as Lord Advocate, was familiar with this problem. As he has observed (in "The Form and Language of Legislation” ( 1999) 18 Rechtshistoriches Journal 601, 633):

"We quite often come across sections in Acts which seem to be badly, or at least obscurely, drafted. Equally often, harsh words are said about the draftsmen of those sections. Here again the blame may lie elsewhere. Problems of drafting are often caused by some amendment which the Government has decided to make in another part of the Bill at a late stage in its passage through Parliament, perhaps in deference to a point made by the Opposition or by its own back benchers. The change may require to be made very quickly and, in the rush, almost inevitably some consequential amendment to another provision is missed and so the problem arises. More interestingly perhaps, even where some difficulty with the drafting is spotted in time to put it right, there may be good reasons why nothing is done to cure it. Once more, the reasons are likely to be political, to do with the need to get the particular Bill, and indeed other Bills, through Parliament."

That was his experience at Westminster. There is no reason to think that the pressures to which he refers are any the less at Holyrood.

Two examples may be given of Bills which have suffered as a result of these shortcomings: the Protection of Wild Animals (Scotland) Act 2002 (asp 6) and the Land Reform (Scotland) Act 2003 (asp 2). The Protection of Wild Animals (Scotland) Bill was originally introduced as a Member's Bill to prevent wild mammals from being hunted by dogs, an area of great controversy. Seventeen such Bills have been introduced at Westminster since 1980. None of them has yet reached the statute book. As one commentator has observed, the fact that the Scottish Parliament has succeeded where Westminster has failed will be regarded either as testimony to the new institution's effectiveness in taking a moral stand and translating it into legislation, or evidence of a disquieting tendency of MSPs to adopt populist policies at the expense of the freedoms and liberties of a particular section of the community (see the General Note to the Act in Current Law Statutes by Mike Radford, School of Law, Aberdeen University).

There is no doubt that the political pressures in favour of getting the Protection of Wild Animals Bill through the Parliament were very great. The Rural Development Committee, which had the responsibility of considering the Bill in principle at Stage 1 and advising the Parliament whether that principle should be agreed to, concluded that the Bill as introduced suffered from significant defects. It divided on the issue, but recommended by a majority that it would be difficult if not impossible to amend the Bill into a form that would adequately meet the aim of ending cruelty to animals. It recommended that the general principles of the Bill should not be agreed to. But its conclusion was rejected after a full debate by the Parliament, and the Bill was returned to the committee for detailed deliberation under Stage 2. The Bill received the Royal Assent on 15 May 2002. Even before it was brought into force on 1 August 2002 its validity was being challenged in the courts. In Adams v The Scottish Ministers, 2003 SLT 366 a petition for judicial review was brought in the Court of Session by a number of people and organisations in Scotland connected with fox hunting who were aggrieved by the prohibition of an activity in which they had previously engaged. Their petition was dismissed on 31 July 2002, but that decision is under appeal and it seems likely that arguments about the Act's validity will continue for some time. Another challenge which was brought by members of the Berwickshire Hunt and others challenging the competence of the Scottish Parliament to legislate on this issue at all was dismissed on 20 June 2003 (Whaley v The Lord Advocate, 20 June 2003, unreported). In the course of his judgment the Lord Ordinary, Lord Brodie, said that the fact that the Parliament had only one chamber and not two did not affect the powers of the court, which could not act as an upper chamber.

The Land Reform (Scotland) Bill was another measure of a similar character. The aim of this Bill, which has no counterpart in England and Wales, was to give rural communities the right to buy land when it comes up for sale and give the public a right of access to all land. Here too radical policies were being promoted by MSPs which were resisted by a significant body of public opinion on the ground that it affected their rights and liberties. On this occasion there was no disagreement between the relevant committee and the Parliament. But the scrutiny of the Bill by the Justice Committee at a series of meetings at which evidence was taken seems to have fallen well short of the expectations of those who had understood that the committee system would enable people from all walks of life to be given a proper hearing, with their evidence heard by cross-party groups who would cross-question them to ensure a fair and equitable outcome. Magnus Linklater, a distinguished journalist and regular commentator on the 
work of the Parliament, was moved to say in the Scotland on Sunday (1 December 2002, p 18) after reading through the reports of the meetings held by this committee:

"As I began to read, I was struck by two things - first of all the blatant, and often self-confessed bias of its members against landowners, farmers and their representatives. Second, the almost wilful refusal to accept evidence which challenged the thrust of the Bill. Those who lobbied for open access to land, or who campaigned for wider distribution of property were listened to with respect and deference, and often called back to give further evidence. Those who sought to defend the rights of property-owners were exposed to truculent and often offensive questioning. The net result is a Bill that has gone further in the direction of radical change than was ever envisaged by the late Donald Dewar when he outlined its purposes - but without the stringent analysis of the legal implications that should have accompanied it."

There is another area of work affecting devolved matters that is in danger of receiving less attention from the Scottish Parliament than it should have if the Parliament is to do its work properly. This is legislation, both primary and delegated, affecting Scotland which is made under the Sewell Convention at Westminster. It was widely assumed that one of the consequences of devolution would be that Parliament at Westminster would no longer legislate on devolved matters, or at least if it did so this would be only in exceptional and limited circumstances. But this has not happened. It has been found to be convenient in practice to allow Westminster to continue to legislate in devolved matters by the use of Sewell motions when it is legislating for England and Wales in the same subject matter. The frequency with which this occurs, and the fact that this is the product of agreements between executives rather than between parliaments, has attracted criticism (see Noreen Burrows, This is Scotland's Parliament; Let Scotland's Parliament Legislate [2002] JR 213; Report of the Select Committee of the House of Lords on the Constitution: Inter-Institutional Relations in the United Kingdom (2nd Report, HL Paper 28, Session 2002-2003)).

The Proceeds of Crime Act 2003 (2002, c 29) provides a good example of this practice. The Nationality, Immigration and Asylum Act 2002 (2002, c 41) provides another. The purpose of the Proceeds of Crime Act was to reform the law relating to the removal of the proceeds of crime from those convicted of certain crimes. The policy to which it seeks to give effect applies to the whole of the United Kingdom, so it made sense to include the Scottish provisions in it. Another reason for preferring to legislate in this way in areas such as these, which are particularly sensitive to objection on human rights grounds, is that it removes the risk of a Bill being found to be outside competence after enactment. The Scottish Parliament does not enjoy parliamentary sovereignty: under the Scotland Act 1998, s 29(4) it cannot pass measures which are incompatible with the European Convention on Human Rights. It is not just that the Bill would have to be immune from challenge at the outset. Amendments which might have the effect of taking a Bill outside its competence would have to be rejected too. As for delegated legislation, Professor Colin Reid has warned that the concentration on politics in Edinburgh should not mask the true significance of powers being exercised in London where more law for Scotland is made than is made by the Scottish Executive (Colin T Reid, "Who makes Scotland's Law? Delegated Legislation under the Devolution Arrangements" (2002) 6 Edinburgh Law Review 380).

The Scottish Parliament has a mandatory subordinate legislation committee which has the functions of the equivalent committees at Westminster, but these functions do not extend to the scrutiny of United Kingdom statutory instruments. There is also some room for doubt as to whether Scottish delegated legislation itself is as yet being adequately scrutinised: for a detailed examination of the early operation of the procedures of this committee, see Chris Himsworth, "Subordinate legislation in the Scottish Parliament” (2002) 6 Edinburgh Law Review 356.

There is reason to be concerned about the extent to which these and similar measures are receiving appropriate scrutiny. The contrary argument is that Scottish MPs will scrutinise the legislation on behalf of members of the Scottish Parliament. But the ability of Ministers in both Houses at Westminster to deal with matters affecting Scotland in the devolved areas has been much reduced since devolution. This tends to affect the amount of attention which the provisions relating to Scotland receive during debates in these Houses. There is not much point in engaging in debate or asking detailed questions about Scottish matters if the Minister at the Despatch Box is unable to deal with these issues and has to refer them back to Ministers of the Scottish Executive in Edinburgh. Suggestions that the Procedures Committee of the Scottish Parliament should be asked to review the procedures for obtaining the Parliament's consent to Westminster legislation have, so far, gone unheeded (see Alan Page and Andrea Batey, "Scotland's Other Parliament: Westminster Legislation about Devolved Matters in Scotland since Devolution” [2002] Public Law 510, 522).

Proposals that legislation that has been proposed for England and Wales on gender recognition and same-sex registered partnerships should be extended to Scotland by adding Scottish provisions onto each Bill in pursuance of a Sewell motion, with the result that these issues will be dealt with for Scotland at Westminster, has added further fuel to this debate (Editorial, "The Executive abdicates responsibility”, 2003 SCOLAG LJ 138 (August 2003).

\section{THE CASE FOR A SECOND CHAMBER IN THE SCOTTISH PARLIAMENT}

It is hardly surprising that the unicameral system in what is, after all, still a very youthful legislature should fall short of the high standards which we have come to expect by way 
of Parliamentary scrutiny. All the debates on legislation, both in committee and before the whole Parliament, are conducted in public. This means that they are conducted under the constant gaze of the press, which is very active in its reporting of what goes on and often highly critical. Government is by coalition, there is a strong socialist and green element and the largest opposition party is the Scottish National Party which tolerates devolution but sees it only as a step towards complete independence from the UK. The main concern of politicians in that environment is with their public image. Nice points about the precise wording of legislation have little appeal.

Public debate on the idea that there should be a second chamber began with an article by Duncan Hamilton, an SNP member of the Scottish Parliament, which was published in the Scotsman newspaper on 31 March 2002 under the heading "The choice facing Holyrood: reform or stagnate". One of the issues which he addressed in this article was the way the Parliament was making law. As he pointed out, the Constitutional Steering Group which drew up the framework for the new Parliament put great emphasis on a new process for law making. It was to be inclusive and transparent and the work of the parliamentary committees was to be at the core of decision making. But his experience of the system in practice, especially during the passage through the system of the Protection of Wild Animals (Scotland) Bill, had led him to question whether the present system contained the necessary checks and balances to ensure robust and effective scrutiny of legislation. He said that the status of committee recommendations, which had been rejected in the case of that Bill by the whole Parliament, had to be bolstered or thought be given to the creation of a second chamber if Parliament was to fulfil its task of passing good law.

Debate on the issue of a second chamber was further excited by an interview with the previous Presiding Officer of the Scottish Parliament, Sir David Steel, which was published by the Scotsman on 26 December 2002. He said that he had, in the light of experience, come to favour a system whereby a Bill would receive further scrutiny by a small part-time, wholly appointed second chamber - a panel of "wise men" (a panel of "wise persons" would be the more politically correct phrase) - after it had been passed by the Parliament. He saw its sole function as that of revising all proposed legislation after it had completed its passage through the elected legislature. This would provide an opportunity for detailed consideration in a less politically-pressurised environment from a more politically detached and perhaps better informed perspective, free of party whips and leadership control of the career development of the elected members. His suggestion was that such a system would offer the prospect, at least from a technical point of view, of an improvement in the quality of legislation emanating from the Parliament. Similar views were expressed by Sir lay Campbell of Succoth in his reply to a survey about voting intentions in the elections to the Scottish Parliament in May 2003 (published in The Scottish Review, May 2003, p 27).

Sir David Steel's observations were not well received by the elected members. This was hardly surprising. It was misconstrued, and misreported, as a suggestion that there should be a second chamber - the very thing that he had been careful to avoid. In a letter to the Times which was published on 30 January 2003 he denied that he had been proposing a Scottish version of the House of Lords. But the idea that there should be a second chamber has received further support from a highly respected academic lawyer, Professor Hector MacQueen of the University of Edinburgh (essay in The Scotsman, 11 March 2003, p 9; see also What Future for Scotland? Policy Options for Devolution, published on 13 March 2003 by the Policy Institute).

Professor MacQueen points out that, although unicameral systems are the norm in the Nordic countries, bicameralism is common in democracies in the Englishspeaking world and that it has been adopted in Germany, France and Italy. It provides an opportunity for second thoughts. Is not unknown at sub-state level, as state legislatures in the United States and in Australia are typically bicameral. The critical issues which he has identified lie in the detail. They are the manner of appointment to the second chamber and the extent of the powers that it would have in relation to the rest of the Parliament and the executive. He has taken the idea beyond the panel of wise persons that Sir David Steel has suggested. He suggests that it should be no larger than 50 persons, of whom perhaps half might be elected in some way or other and include territorial or regional representatives, that it should not necessarily be full-time, that it should not be controlled or controllable by any party or combination of parties, that it should have the power to require reconsideration but generally not to prevent the passage of legislation from the other chamber and that it should have other functions such as the initiation of noncontentious legislation, constitutional and other public interest scrutiny of legislation and of other public actions and decision-making. To that list he added as an important consideration relations between the Parliament and other institutions of government in the UK and the EU. Although he did not say so in terms, I believe that this would provide an opportunity for the more effective scrutiny of proposed legislation by the European Union and of legislation in devolved areas which is being handled at Westminster. These are important areas of work where the Parliament in its present form appears to be falling short of what is required.

There is no doubt that the introduction of a second chamber into the present system in Scotland would be contentious. As Professor MacQueen observed, the case for the functions often performed by second chambers as a necessary element is really uncontroversial. The question whether one is needed in Scotland is the question which 
excites controversy. Primary legislation would be required to amend the Scotland Act, and it would have to be preceded by a period of consultation. Politically, this may prove to be too much a mountain to climb for the time being. Although the late Donald Dewar said that devolution was a process, not an event, review of the present structure risks opening up much wider and more fundamental issues. The whole system is likely to remain precarious so long as the Scottish National Party continues to command a high level of support among the electorate. But the arguments in favour of its introduction are, I believe, compelling. Properly handled, such a reform would be likely to produce a marked improvement in the quality of the work done by the Parliament.

\section{SCRUTINY OF EUROPEAN LEGISLATION AT WESTMINSTER}

As everyone knows, the primary responsibility for legislation in this country rests with Parliament. It is not the primary responsibility of the executive. What then are we to make of legislation that emanates from the EU? EU legislation is made by the Council of Ministers. National parliaments have no part to play in that process. The Council of Ministers, as the name suggest, is composed of ministers drawn from the member states - members of the executive. Moreover, the content of a regulation or a directive is settled when it emerges from Brussels. It then has to be implemented in accordance with the obligations imposed on all member states by Article 234 of the Treaty. So it is a matter of great importance that those who prepare this legislation on behalf of the EU should be subject to scrutiny. As legislation is a matter for Parliament, there has to be role in this process for Parliament. That role is to scrutinise the proposed measure before assent is given to it to ensure, so far as possible, that it is appropriate that the citizens of our country should be required to comply with it.

The scrutiny of EU legislation at Westminster is conducted by both Houses of Parliament. EU documents are deposited in Parliament along with an explanatory memorandum prepared by the relevant department of the UK Government. This memorandum sets out the government's views on the policy implications of the proposal and the timetable for its consideration by the Council. These documents are then examined separately by two committees, the European Scrutiny Committee in the House of Commons and the Select Committee on the European Union in the House of Lords. Where necessary the committees then comment on these documents by way of a report to the House or a letter to the Minister. The word "scrutiny" is interpreted by the House of Lords Select Committee in its broadest sense, namely a process of examination and analysis of the proposals and actions of those responsible for the government with a view to ensuring that they are accountable for their actions to Parliament (Review of Scrutiny of European Legislation (1st
Report, Session 2002-03, HL Paper 15), para 8). It has been defined for their purposes by the House of Commons Scrutiny Committee in these terms:

"To ensure that members are informed of EU proposals likely to affect the United Kingdom, to provide a source of information and analysis for the public and to ensure that the House and the European Scrutiny Committee, and through them other organisations and individuals, have opportunities to make Ministers aware of their views on EU proposals, seek to influence Ministers and hold Ministers to account."

The key to the system in the House of Lords is a scrutiny reserve resolution which was passed by the House of Lords on 6 December 1999 (the full text of this resolution is set out in Appendix 3 to the Report). It is intended to ensure that Ministers do not agree to EU legislation in the Council unless and until the House's scrutiny of it is complete. It gives the House an opportunity to influence the position which the Government is adopting on the proposal in negotiation with other member states of the Community. It states that no Minister of the Crown should give agreement in the Council to any proposal for European Community legislation on which the European Union Committee has not completed its scrutiny or on which the Committee has made a report to the House for debate but on which the debate has not taken place. In other words, the effect of the resolution is to bar Ministers from giving agreement in Council to any proposal which has not been cleared from scrutiny. Ministers can override the reserve if they consider that for special reasons agreement should be given to it, but they must give an explanation when they do so. A similar scrutiny reserve resolution operates in the House of Commons.

The committees of the two Houses differ in the methods which they adopt when they are carrying out this process. The House of Lords Committee has, in addition to the main committee, six sub-committees whose members have expertise in six different policy areas: economic and financial affairs, environment and agriculture, law and institutions, social affairs and so on. Under the current arrangements, which will be brought to an end with the setting up of the proposed new Supreme Court, a serving Lord of Appeal in Ordinary serves for three years as chairman of the sub-committee on law and institutions: my immediate predecessors as chairman were Lords Slynn of Hadley and Lord Hoffmann and my successor is Lord Scott of Foscote. About 70 members of the House serve on these various committees, so a very wide range of knowledge and experience is brought to bear on their work. As the various documents are deposited for scrutiny they are sifted by the Chairman who, having examined the document and the explanatory memorandum, decides whether it should be referred to one of the subcommittees for examination or should be cleared at once from scrutiny. The purpose of the sift is to ensure that the Committee focuses its attention on significant documents. 
About a quarter of all the documents deposited in Parliament are sifted to the sub-committees. The number of documents deposited has been increasing steadily year after year and is now about 1,400. So about 385 documents find their way to the House of Lords subcommittees each year for detailed scrutiny. The House of Commons Scrutiny Committee does not examine the documents on their merits, it has no sub-committee and there is no sift. It considers them all and reports to the House whether they are legally or politically important and thus worthy of debate. If there is a debate it normally takes place in a European Standing Committee or, occasionally, on the floor of the House of Commons. The debate is responded to by the relevant Minister. The Scrutiny Committee may however correspond with Ministers if more information is required before a decision is taken as to whether there should be a debate. The scrutiny reserve remains in operation while that information is being sought.

The scrutiny reserve system thus plays a vital role in this process. Its purpose is to ensure, except in special cases, that the process of scrutiny is completed in both Houses before the proposed measure is agreed to in Council by the relevant Minister. It does not require the Government to agree with the views expressed by either House, nor does it require a Minister to obtain a mandate from Parliament before negotiating a position in Council on behalf of the Government. Nevertheless a great deal of effort is expended in order to ensure that the scrutiny is as effective as possible. There is, after all, a clear constitutional purpose in this exercise. If it is to serve this purpose it should include the following: (a) gathering together relevant material with a view to informing the House and the public about what is being proposed, (b) drawing attention to significant issues and making recommendations on them for consideration by Ministers, (c) subjecting the draft text to detailed analysis by exposing difficulties and proposing amendments as part of the process of law-making.

In combination the EU Committees of both Houses provide a valuable check on the work done by Ministers in this area. But the strength of their contribution lies in the different ways in which they operate. The selective and detailed approach of the House of Lords Committee and its various sub-committees is widely admired throughout the EU. It has helped to create a culture in which the government accepts that it has to justify the decisions which it takes on our behalf in the Council of Ministers. This in its turn has done much to enhance the reputation generally, and among the institutions of the EU in particular, of the system of scrutiny of EU legislation at Westminster.

\section{CONCLUSION}

The importance of parliamentary scrutiny cannot be overstated. The quality, legality and democratic legitimacy of the legislation by which our activities are increasingly being regulated is a matter of concern to us all. Our Parliaments would be failing in their duty if they were unable to ensure that the legislation which they enact measures up to these requirements.

That is the context in which the contribution that second chambers can make should be judged. One often hears criticisms that the second chamber at Westminster is undemocratic and that it exists simply as an obstacle to the passage of measures that have the support in the other, elected chamber of the majority. Similar criticisms are made of the suggestion that a second chamber should be introduced into the Scottish Parliament. But they divert attention from the only relevant question, which relates to the functions which a second chamber is designed to serve. That question is whether the second chamber can add value to the process of legislative scrutiny. That is the starting point for an examination of its constitutional legitimacy and its utility. I believe that the reputation of the Westminster Parliament would be seriously weakened if it were to be deprived of the services of its second chamber, and that the quality of the work done by Scottish Parliament would be enhanced if it were to acquire one. (c)

Lord Hope of Craighead 